\title{
Evaluasi Pertumbuhan Bibit Aren (Arenga pinnata (Wurmb) Merr.) terhadap Pemupukan $P$ dan Inokulasi Fungi Mikoriza Arbuskula
}

\section{Growth Evaluation of Sugar Palm (Arenga pinnata (Wurmb) Merr.) Seedling with Phosphor Fertilization and Inoculated Arbuscular Mycorrhizal Fungi}

\author{
Maria Paulina $^{1)^{*}}$, Irdika Mansur ${ }^{2)}$, \& Ahmad Junaedi ${ }^{3}$ \\ ${ }^{1)}$ Program Studi Agroteknologi, Fakultas Pertanian, Universitas Bina Insan Lubuk Linggau \\ ${ }^{2)}$ Departemen Silvikultur, Fakultas Kehutanan, Institut Pertanian Bogor \\ ${ }^{3)}$ Departemen Agronomi dan Hortikultura, Fakultas Pertanian, Institut Pertanian Bogor \\ Email : mariapaulina@univbinainsan.ac.id ${ }^{1)^{*}}, \underline{\text { irdikam@gmail.com }}^{2)}$, junaedi_agr@ipb.ac.id ${ }^{3)}$
}

\begin{abstract}
ABSTRAK
Aren merupakan salah satu jenis tanaman yang potensial untuk dikembangkan, karena seluruh bagian tanamannya dapat dimanfaatkan. Pembudidayaan aren saat ini masih bersifat tradisional dan masih kalah jauh dari jenis famili arecaceae lainnya. Penelitian dilaksanakan dari bulan Agustus - Oktober 2016 di lokasi pembibitan, dan analisis tipe spora maupun kolonisasi FMA di laboratorium Silvikultur SEAMEO BIOTROP Bogor. Penelitian ini dilakukan pada bibit aren yang telah berumur 19 bulan. Penelitian ini menggunakan Rancangan Acak Lengkap dengan 2 faktor yaitu pemupukan $P$ dan inokulasi FMA. Faktor pemupukan $P$ memiliki 2 taraf yaiu tanpa pemupukan $P$ dan diberi pemupukan P. Faktor inokulasi FMA terdiri atas 3 taraf yaitu tanpa inokulasi FMA, FMA indigenous, dan FMA mycofer. Hasil penelitian menunjukkan bahwa perlakuan pemupukan $P$ dan inokulasi FMA tdak berpengaruh untuk semua peubah yang diamati yaitu tinggi tanaman, jumlah pelepah daun, panjang rachis, diameter tanaman, kehijauan daun, jumlah spora dan kolonisasi akar. Penelitian ini juga menemukan 3 genus spora pada bibit aren yaitu Acaulospora sp., Gigaspora sp., dan Glomus sp, serta terdapatnya 2 jenis infeksi akar berupa hifa dan vesikula.
\end{abstract}

Kata kunci: Arenga pinnata, glomus, kolonisasi akar, mikoriza, spora.

\section{ABSTRACT}

Aren is one type of plant that has the potential to be developed because all parts of the plant can be used. Currently, the cultivation of sugar palm is still traditional and far less than other types of Arecaceae family. The research was conducted from August to October 2016 at the nursery site, and analysis of spore types and AMF colonization in the SEAMEO BIOTROP Bogor Silviculture Laboratory. This research was conducted on palm seedlings that were 19 months old. This study used a completely randomized design with 2 factors, namely $P$ fertilization and AMF inoculation. The $P$ fertilization factor has 2 levels, namely without $P$ fertilization and given $P$ fertilization. The inoculation factor for AMF consisted of 3 levels, namely without AMF inoculation, indigenous AMF, and my cover AMF. The results showed that $P$ fertilization treatment and AMF inoculation did not significantly affect all observed variables, namely plants, number of leaf midribs, length of rachis, plant diameter, SPAD value, number of spores, and root colonization. There was 3 genus of spores, namely Acaulospora sp., Gigaspora sp., and Glomus sp., as well as 2 types of root infections in the form of hyphae and vesicles.

Keywords: Arenga pinnata, glomus, root colonization, mycorrhizae, spores.

Article History Submitted: November 9, 2020 Approved with minor revision: December 11, 2020 Accepted: December 12, 2020 Published: December 29, 2020

\section{PENDAHULUAN}

Aren (Arenga pinnata) merupakan salah satu jenis tanaman perkebunan yang memiliki prospek untuk dikembangkan. Tanaman aren termasuk ke dalam suku pinang-pinangan (arecaceae) bersama dengan beberapa komoditi perkebunan 
seperti kelapa, kelapa sawit, pinang. Berdasarkan (KEMENTAN, 2016), luas areal tanaman Aren sampai tahun 2014 hanya seluas $61930 \mathrm{Ha}$, dengan produksi sebesar 53393 ton, masih jauh tertinggal dibandingkan kelapa 3609812 Ha dengan produksi 3005916 ton, kelapa sawit sebesar $10754801 \mathrm{Ha}$ dengan produksi 5 556401 ton dan pinang $137041 \mathrm{Ha}$ dengan produksi 46972 Ton.

Populasi aren menjadi berkurang karena disebabkan oleh kerusakan hutan maupun konversi kawasan hutan untuk peruntukan lain yang tidak diimbangi dengan proses kegiatan budidaya yang mumpuni (Lempang, 2012). Kedepannya perlu kebijakan yang dibuat antara pemerintah pusat dan daerah dalam pengembangan tanaman aren agar mampu memperbaiki dari manajemen produksi sampai ke pemasaran (Sebayang, 2016) .

Manfaat yang diperoleh dari tanaman aren yaitu ijuk yang berguna untuk tambang, atap dan sapu; tepung aren yang dapat dibuat menjadi cendol, soun, bahan baku mie; nira yang bisa diolah menjadi minuman segar, cuka dan gula aren; kolang-kaling. Selain itu, tanaman aren juga mampu menghasilkan bioetanol dan juga mampu sebagai tanaman penahan erosi karena memiliki akar yang panjang. Bioetanol yang mampu dihasilkan oleh aren adalah sebesar 1.43 juta KL tahun ${ }^{-1}$ (Effendi, 2010).

Limbah kulit buah aren juga berpotensi sebagai pupuk organik cair dan pupuk kompos. Perlakuan dosis pupuk organik cair yang berasal dari kulit buah aren memperlihatkan pengaruh nyata terhadap jumlah polong hampa (Novita, Kesuma, \& Susilo, 2017). Menurut (Utari, 2018) buah aren yang banyak dimanfaatkan dalam industri makanan menghasilkan limbah kulit buah aren yang digunakan sebagai biomassa tanaman, sehingga dapat menekan terbuangnya jumlah limbah padat aren.

Secara umum, pembudidayaan tanaman aren belum dilakukan secara intensif. Tanaman aren kebanyakan tumbuh secara alami tanpa ada tindakan khusus dalam pembudidayaannya.
Sehingga, tak heran kalau produktivitasnya masih tergolong rendah. karena itu, perlu dilakukan suatu usaha demi meningkatkan produktivitas tanaman aren yaitu dengan pemupukan. Pemupukan bisa dilakukan dengan pemberian pupuk organik maupun pupuk anorganik. Pupuk organik bisa dari pupuk kompos, pupuk organik cair atau pun pupuk hayati.

Salah satu jenis pupuk hayati adalah fungi mikoriza arbuskula (FMA). Adapun fungsi FMA sebagai bioprosesor yaitu mampu membantu tanaman dalam menyerap air dan hara yang tidak mampu dijangkau oleh rambut akar (Nusantara, Bertham, \& Mansur, 2012). Produksi tanaman kedelai di tanah ultisol meningkat dengan pemberian FMA yang terlihat pada variabel jumlah polong per tanaman, bobot polong per tanaman, jumlah biji per tanaman, dan bobot 20 butir biji (Malik, Hidayat, Yusnaini, \& Rini, 2017). Jenis fungi mikoriza berpengaruh nyata dengan parameter bobot berangkasan segar fase vegetatif, bobot akar segar fase vegetatif, bobot berangkasan kering fase vegetatif, bobot akar kering fase vegetatif dan panjang akar fase vegetatif serta berpengaruh nyata terhadap serapan hara nitrogen (Hadianur, Syafruddin, \& Kesumawati, 2016).

Penambahan pupuk organik sebesar 25-50\% yang dikombinasikan dengan 50 $75 \%$ pupuk anorganik berpengaruh terhadap parameter rata-rata pertambahan tinggi tanaman, rata-rata pertambahan lilit batang dan jumlah daun pada tanaman aren yang belum menghasilkan (TBM) (Ariyanti, Soleh, \& Maxiselly, 2017). Paramater diameter batang bibit aren pada umur 2, 4, 6 MSPT berpengaruh nyata terhadap pupuk organik cair yang digunakan (Manahan, Putri, \& Husni, 2014). Pemberian pupuk organik sebanyak $400 \mathrm{~g}_{\text {pohon }}{ }^{-1}$ tahun $^{-1}$ memberikan respon pertumbuhan yang baik pada tanaman aren belum produktif, yaitu pertambahan tinggi tanaman $158.82 \mathrm{~cm}$, lingkar batang 70.80 $\mathrm{cm}$, jumlah daun 10.25 serta panjang daun $481.67 \mathrm{~cm}$ (Mashud, Maliangkay, \& Nur, 2013). 
Jumlah polong per tanaman seiring dengan peningkatan dosis pupuk $\mathrm{P}$ yang diberikan pada tanaman buncis yaitu 98.32 $\mathrm{kg} \mathrm{ha}^{-1}$ dengan jumlah polong sebanyak 24.58 buah. Selain itu, dosis pupuk $\mathrm{P}$ juga mampu meningkatkan berat polong segar per tanaman yaitu 157.72 gram per tanaman dengan dosis optimal sebanyak $98.49 \mathrm{~kg} \mathrm{ha}^{-1}$ (Nuryani, Haryono, \& Historiawati, 2019).

Waktu aplikasi fosfor pada 0 dan 4 MST di tanah mineral bergambut mampu meningkatkan pertumbuhan dan produktivitas tanaman kedelai. Selain itu, interaksi varietas tanggamus dengan pemberian pupuk $\mathrm{P}$ sebanyak dua kali yaitu dengan dosis $73 \mathrm{~kg} \mathrm{P}_{2} \mathrm{O}_{5}$ per hektar pada 0 dan 4 MST menghasilkan 3.8 ton $\mathrm{ha}^{-1}$ di tanah mineral dan 2.8 ton $\mathrm{ha}^{-1}$ di tanah mineral bergambut (Bachtiar, Ghulamahdi, Melati, Guntoro, \& Sutandi, 2016).

Penelitian ini bertujuan untuk mengevaluasi pertumbuhan, karakteristik tipe spora FMA dan kolonisasi akar bibit aren yang telah berumur 19 bulan selama berada di pembibitan.

\section{METODE PENELITIAN}

Penelitian telah dilaksanakan dari bulan Agustus - Oktober 2016. Adapun tempat penelitian yaitu lokasi pembibitan, dan analisis tipe spora maupu kolonisasi FMA dilaksanakan di laboratorium Silvikultur SEAMEO BIOTROP.

Bahan penelitian ini yaitu bibit aren berumur 19 bulan, sekaligus dilakukan penelitian termasuk proses pemangkasan pelepah daun. Di akhir pengamatan, dilakukan pengambilan sampel akar dan tanah dari masing-masing polibag bibit aren, aquades, larutan glukosa $60 \%$, larutan $\mathrm{KOH} 10 \%, \mathrm{HCl} 2 \%$, glyserin, polyvynil alkohol lactogliserol (PVLG), trypan blue dan larutan Melzer. Adapun alat yang dipergunakan dalam menunjang penelitian ini adalah alat ukur (meteran), jangka sorong, Chlorophyll meter, timbangan, kertas label, kaca preparat, kaca penutup, saringan bertingkat 4 yaitu ukuran lubang $425 \mu \mathrm{m}, 212 \mu \mathrm{m}, 106 \mu \mathrm{m}$ dan $63 \mu \mathrm{m}$, sentrfuse, tabung sentrifuse, pinset spora, mikroskop binokuler Olympus CX-21, cawan petri, dan pipet tetes.

Sebelum menjadi bibit, benih arennya diperoleh dari populasi tanaman aren yang telah berumur di atas 15 tahun di daerah Cianjur, Jawa Barat. Inokulum FMA indigenous diambil dari tanah di bawah tegakan aren yang telah melalui proses penangkaran, namun untuk inokulum FMA mycofer berasal dari laboratorium Bioteknologi Hutan dan Lingkungan, Institut Pertanian Bogor. Inokulum FMA mycofer mengandung Gigaspora margarita, Glomus mosae dan Glomus intradises (Miska, 2015).

Setelah penelitian yang dilakukan oleh (Miska, 2015) selesai, maka bibitbibit aren tetap dibiarkan berada di lokasi pembibitan SEAMEO BIOTROP. Selanjutnya, dilakukan pengecekan terhadap bibit-bibit aren tersebut lalu dilakukan pengelompokan terhadap bibitbibit aren sesuai dengan perlakuannya yaitu $\mathrm{P}_{0} \mathrm{M}_{0}$ (tanpa pemupukan $\mathrm{P}$; tanpa FMA), $\mathrm{P}_{0} \mathrm{M}_{1}$ (tanpa pemupukan $\mathrm{P}$; FMA indigenous), $\mathrm{P}_{0} \mathrm{M}_{2}$ (tanpa pemupukan $\mathrm{P}$; FMA mycofer), $\mathrm{P}_{1} \mathrm{M}_{0}$ (pemupukan $\mathrm{P}$; tanpa FMA), $\mathrm{P}_{1} \mathrm{M}_{1}$ (pemupukan $\mathrm{P}$; FMA indigenous), dan $\mathrm{P}_{1} \mathrm{M}_{2}$ (pemupukan $\mathrm{P}$; tanpa FMA mycofer).

Pelepah daun yang sudah menguning maka dipangkas/dibuang, sehingga pada setiap bibit tanaman menyisakan sekitar 3-4 pelepah. Bibit aren yang digunakan dalam penelitian ini adalah bibit-bibit aren dengan tinggi yang sama, supaya seragam dalam memperoleh data pengamatan. Jika polibag yang lama sudah rusak, maka dilapisi dengan polibag yang baru dengan ukuran yang sama. Lokasi percobaan berada di pembibitan SEAMEO BIOTROP. Setiap bibit aren yang berada di polibag diberi jarak sekitar $40 \mathrm{~cm}$.

Rancangan penelitian ini mengikuti dari penelitian sebelumnya (Miska, 2015) yang menggunakan Rancangan Acak lengkap (RAL) dengan 2 faktor, dimana faktor 1 pemupukan yaitu tanpa pemupukan $\mathrm{P}\left(\mathrm{P}_{0}\right)$ dan pemupukan $\mathrm{P}\left(\mathrm{P}_{1}\right)$ sebanyak $6.3 \mathrm{~g}$ (berbentuk SP36), dan 
faktor 2 inokulasi FMA yaitu tanpa FMA $\left(\mathrm{M}_{0}\right)$, FMA indigenous $\left(\mathrm{M}_{1}\right)$, dan FMA mycofer $\left(\mathrm{M}_{2}\right)$. Dalam satu unit percobaan terdiri atas 3 tanaman dan terdiri dari 4 ulangan, sehingga secara keseluruhan terdapat 72 bibit aren. Model statistika yang dipergunakan adalah sebagai referensi :

$$
Y i j k=\mu+\alpha i+\beta j+(\alpha \beta) i j+\varepsilon i j k
$$

Keterangan

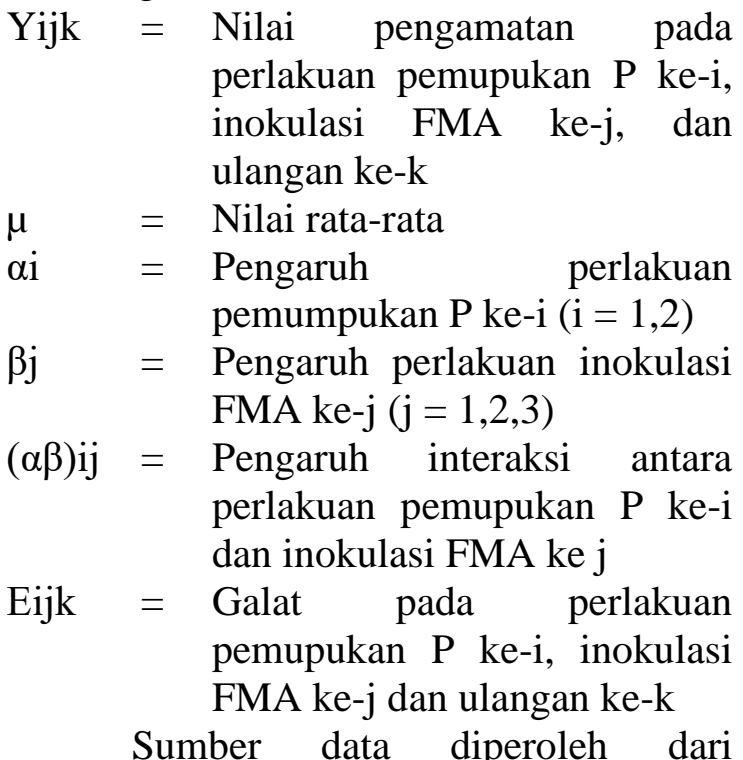
pengamatan bibit aren selama 2 bulan. Data-data yang diperoleh dari hasil pengamatan dianalisis dengan uji $\mathrm{F}$ pada taraf $\alpha 5 \%$. Apabila terdapat pengaruh yang nyata, maka dilanjutkan dengan uji DMRT pada taraf $\alpha 5 \%$. Selanjutnya, datadata tersebut diolah menggunakan program SAS Windows 9.1.3.

Pengamatan dilakukan pada bibit aren yang telah berumur 19 bulan selama 4 minggu kecuali kolonisasi akar dan identifikasi spora dilakukan di akhir penelitian. Adapun variabel pengamatan yang diamati, seperti :

1. Tinggi tanaman $(\mathrm{cm})$; pengukuran menggunakan alat ukur (meteran) mulai dari pangkal batang hingga titik tumbuh.

2. Jumlah pelepah daun (helai); pelepah daun yang dihitung merupakan pelepah daun yang telah membuka sempurna.

3. Panjang rachis $(\mathrm{cm})$; panjang rachis diukur dari anak daun pertama sampai ujung daun.

4. Diameter tanaman ( $\mathrm{mm})$; pengukuran diameter dilakukan pada bagian $1 \mathrm{~cm}$ dari pangkal pelepah menggunakan jangka sorong.

5. Kehijauan daun; pengukuran kehijauan daun menggunakan Chlorophyll meter SPAD-502.

6. Kolonisasi akar (\%); perhitungan kolonisasi akar menggunakan rumus (Brundrett, Bougher, Dell, Grove, \& Malajczuk, 1996), yaitu:

$\%$ Kolonisasi akar oleh FMA =

$\frac{\text { jumlah bidang pandang yang terkolonisasi FMA }}{\text { jumlah keseluruhan bidang pandang }} \times 100 \%$

7. Identifikasi spora; pengamatan identifikasi spora dilakukan secara deskriptif. Pengidentifikasian FMA dilakukan sampai tingkat genus dengan melihat bentuk, warna, dan ukuran spora berdasarkan deskripsi morfologis genus FMA (Brundrett, Bougher, Dell, Grove, \& Malajczuk, 1996).

Langkah awal dalam penelitian ini adalah melakukan pengecekan terhadap bibit aren. Bibit-bibit tersebut dikelompokkan berdasarkan perlakuan yang telah ada. Apabila polibagnya sudah rusak, maka dilapisi dengan polibag baru. Setelah itu dilakukan pemangkasan pada pelepah daun yang telah menguning, sehingga setiap polibag hanya menyisakan sekitar 3-4 pelepah daun per polibag. Pemeliharaan meliputi penyiraman yang dilakukan secara rutin setiap hari dan pengendalian gulma yang berada di polibag secara manual yaitu dengan membuang gulma tersebut ke luar area pembibitan.

\section{HASIL DAN PEMBAHASAN}

Hasil

\section{Pertumbuhan Bibit Aren}

Pertumbuhan tanaman dapat dilihat dari adanya pertambahan jumlah dan dimensi tanaman baik tinggi maupun diameter tanaman. Setelah dilakukan pengamatan terhadap bibit aren berumur 19 bulan, didapatlah data seperti Tabel 1 . Variabel pengamatan tinggi tanaman, jumlah pelepah daun, panjang rachis, 
diameter batang, kehijauan daun, jumlah spora dan kolonisasi akar menunjukkan tidak berpengaruh nyata terhadap perlakuan pemupukan $\mathrm{P}$ dan inokulasi FMA. Namun, ada kemungkinan jika pengamatan pertumbuhan ini terus dilakukan maka kemugkinan akan ada peningkatan terhadap tinggi tanaman, jumlah pelepah daun, panjang rachis dan diameter tanaman.

Tabel 1. Rekapitulasi hasil sidik ragam perlakuan pupuk P dan inokulasi FMA terhadap peubah yang diamati pada bibit aren berumur 19 bulan

\begin{tabular}{lccc}
\hline \multicolumn{1}{c}{ Peubah } & Pupuk P $(\mathrm{P})$ & Inokulasi FMA $(\mathrm{F})$ & $\mathrm{P} \times \mathrm{F}$ \\
\hline Tinggi tanaman $(\mathrm{cm})$ & tn & tn & tn \\
Jumlah pelepah daun (helai) & tn & tn & tn \\
Panjang rachis $(\mathrm{cm})$ & tn & tn & tn \\
Diameter $(\mathrm{mm})$ & tn & tn & tn \\
Kehijauan daun $(\%)$ & tn & tn & tn \\
Jumlah spora & tn & tn & tn \\
Kolonisasi akar $(\%)$ & tn & tn & tn \\
\hline
\end{tabular}

Keterangan : $\mathrm{tn}=$ tidak berbeda nyata pada uji $\mathrm{F} 5 \%$

Adapun peubah pertumbuhan yang diamati di Tabel 2. terlihat bahwa variabel pengamatan tinggi tanaman, jumlah pelepah daun, panjang rachis dan diameter tanaman tidak berpengaruh nyata. Hal ini menunjukkan bahwa bibit aren tetap dapat tumbuh walau tanpa perlakuan pemupukan dan FMA sekalipun.

Tabel 2. Pengaruh perlakuan pemupukan $\mathrm{P}$ dan inokulasi FMA terhadap peubah tinggi tanaman, jumlah pelepah daun, panjang rachis dan diameter tanaman

\begin{tabular}{|c|c|c|c|c|}
\hline Perlakuan & $\begin{array}{c}\text { Tinggi } \\
\text { tanaman }(\mathrm{cm})\end{array}$ & $\begin{array}{c}\text { Jumlah pelepah } \\
\text { daun (helai) }\end{array}$ & $\begin{array}{c}\text { Panjang } \\
\text { rachis }(\mathrm{cm})\end{array}$ & $\begin{array}{c}\text { Diameter } \\
\text { tanaman }(\mathrm{mm})\end{array}$ \\
\hline \multicolumn{5}{|c|}{ Pemupukan $\mathrm{P}$} \\
\hline Tanpa pemupukan $\mathrm{P}\left(\mathrm{P}_{0}\right)$ & $136.4^{\mathrm{tn}}$ & $3.5^{\mathrm{tn}}$ & $33.6^{\mathrm{tn}}$ & $37.9^{\text {tn }}$ \\
\hline Pemupukan $\mathrm{P}\left(\mathrm{P}_{1}\right)$ & $128.2^{\operatorname{tn}}$ & $3.3^{\text {tn }}$ & $36.6^{\mathrm{tn}}$ & $38.7^{\mathrm{tn}}$ \\
\hline \multicolumn{5}{|l|}{$\mathrm{T}-2,1)$} \\
\hline Tanpa FMA $\left(\mathrm{M}_{0}\right)$ & $130.2^{\text {tn }}$ & $3.4^{\text {tn }}$ & $35.0^{\mathrm{tn}}$ & $37.0^{\operatorname{tn}}$ \\
\hline FMA indigenous $\left(\mathrm{M}_{1}\right)$ & $127.1^{\mathrm{tn}}$ & $3.5^{\text {tn }}$ & $34.1^{\mathrm{tn}}$ & $38.2^{\text {tn }}$ \\
\hline FMA mycofer $\left(\mathrm{M}_{2}\right)$ & $139.6^{\text {tn }}$ & $3.5^{\text {tn }}$ & $35.9^{\text {tn }}$ & $39.8^{\mathrm{tn}}$ \\
\hline
\end{tabular}

Keterangan : $\mathrm{tn}=$ tidak berbeda nyata pada uji $\mathrm{F} 5 \%$

\section{Kehijauan Daun}

Tabel 3. menunjukkan bahwa perlakuan pemupukan $\mathrm{P}$ dan inokulasi FMA tidak berpengaruh nyata terhadap kehijauan daun. Hal ini diduga karena bibit aren kekurangan unsur hara makro kecuali pemupukan $\mathrm{P}$ yang telah diberikan pada 0 , 45, 90 dan 135 HST (Miska, 2015), dan pemupukan $\mathrm{P}$ yang telah diberikan cepat hilang karena telah mengalami proses pencucian. Pengukuran kadar kehijauan daun menggunakan chlorophyll meter SPAD-502. Nilai yang tertera pada chlorophyll meter SPAD hanya untuk mengetahui kandungan total klorofil yang ada di daun. 
Tabel 3. Pengaruh perlakuan pemupukan $\mathrm{P}$ dan inokulasi FMA terhadap rata-rata nilai kehijauan daun pada bibit aren berumur 19 bulan

\begin{tabular}{lc}
\hline Perlakuan & Kehijauan daun $(\%)$ \\
\hline Tanpa pemupukan $\mathrm{P}\left(\mathrm{P}_{0}\right)$ & Pemupukan $\mathrm{P}$ \\
\hline Pemupukan $\mathrm{P}\left(\mathrm{P}_{1}\right)$ & $38.2^{\mathrm{tn}}$ \\
\hline Tanpa FMA $\left(\mathrm{M}_{0}\right)$ & $37.2^{\text {tn }}$ \\
FMA indigenous $\left(\mathrm{M}_{1}\right)$ & $34.2^{\mathrm{tn}}$ \\
FMA mycofer $\left(\mathrm{M}_{2}\right)$ & $39.2^{\text {tn }}$ \\
\hline
\end{tabular}

Keterangan : $\mathrm{tn}=$ tidak berbeda nyata pada uji $\mathrm{F} 5 \%$

\section{Jumlah Spora}

Pengaruh perlakuan pemupukan $\mathrm{P}$ dan inokulasi FMA pada peubah jumlah spora tidak berpengaruh nyata. Hasil penelitian menujukkan bahwa bibit aren kontrol $\left(\mathrm{M}_{0}\right)$ sudah terinfeksi dan terdapat spora. Adapun jumlah spora FMA pada tiap $10 \mathrm{~g} \mathrm{tanah}^{-1}$ dapat dilihat pada Tabel 4.

Tabel 4. Pengaruh perlakuan pemupukan $\mathrm{P}$ dan inokulasi FMA terhadap jumlah spora pada bibit aren berumur 19 bulan

\begin{tabular}{lc}
\hline Perlakuan & Jumlah spora $10 \mathrm{~g}^{-1}$ tanah \\
\hline Tanpa pemupukan $\mathrm{P}\left(\mathrm{P}_{0}\right)$ & Pemupukan $\mathrm{P}$ \\
Pemupukan $\mathrm{P}\left(\mathrm{P}_{1}\right)$ & $5.0^{\mathrm{tn}}$ \\
\hline & $6.0^{\text {tn }}$ \\
\hline Tanpa FMA $\left(\mathrm{M}_{0}\right)$ & FMA \\
FMA indigenous $\left(\mathrm{M}_{1}\right)$ & $6.0^{\mathrm{tn}}$ \\
FMA mycofer $\left(\mathrm{M}_{2}\right)$ & $5.0^{\text {tn }}$ \\
\hline
\end{tabular}

Keterangan : $\mathrm{tn}=$ tidak berbeda nyata pada uji $\mathrm{F} 5 \%$

\section{Karakterisasi Tipe Spora FMA}

Hasil penelitian ini menunjukkan taksonomi FMA dibatasi hanya sampai tingkat genus. Ditemukan ada 3 jenis tipe spora selama proses isolasi dan identifikasi, yaitu genus Acaulospora,
Gigaspora, dan Glomus, masing-masing 3, 1, dan 8 tipe spora (Tabel 5). Terlihat juga pada Tabel 5. menunjukkan karakteristik yang diamati berupa pengamatan bentuk dan warna yang dilihat secara mikroskopis.

Tabel 5. Karakteristik tipe spora FMA dari bibit aren berumur 19 bulan

\begin{tabular}{ll}
\hline Tipe Spora & Karakteristik Morfologi \\
\hline & $\begin{array}{l}\text { spora berbentuk bulat, jika diberi melzer maka akan berubah warna } \\
\text { menjadi merah gelap, dan memiliki saccule. }\end{array}$ \\
\hline & \\
\hline
\end{tabular}


Bentuk spora bulat, warna cokelat kekuningan, permukaan halus, terdapat reaksi pada bagian dalamnya menjadi jingga, memiliki saccule.

Acaulospora sp. 2

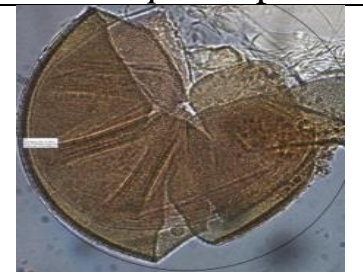

Spora berbentuk bulat, berwarna kecoklatan, permukaan kasar.

Acaulospora sp. 3

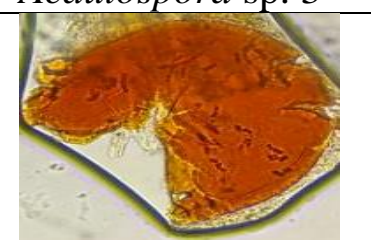

Spora berbentuk bulat, permukaan halus, berwarna kuning kecoklatan.

Gigaspora sp.1

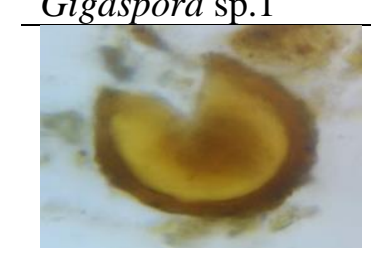

Spora bulat, memiliki dinding yang tebal, berwarna kuning kecoklatan, tidak bereaksi dengan melzer.

Glomus sp. 1

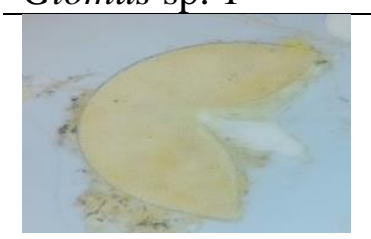

Bentuk spora bulat, berwarna kuning, tidak berekasi dengan melzer.

\section{Glomus sp. 2}

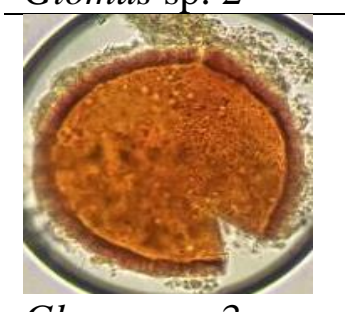

Spora berbentuk bulat, berwarna coklat, memiliki dinding tebal, tidak bereaksi dengan melzer.

Glomus sp. 3

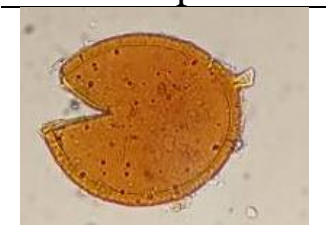

Spora bulat, berwarna cokelat, terdapat hifa, tidak bereaksi dengan melzer, permukaan kasar.

Glomus sp. 4

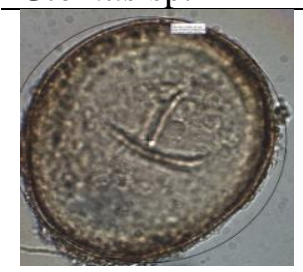

Spora berbentuk elips, berwarna bening kecoklatan, tidak bereaksi dengan melzer, permukaan kasar

Glomus sp. 5 


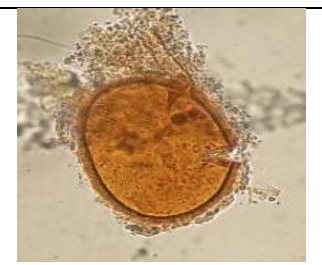

Spora berbentuk elips, berwarna coklat, tidak bereaksi dengan melzer, permukaan kasar.

Glomus sp. 6

\begin{tabular}{ll} 
Glomus sp. 6 & $\begin{array}{l}\text { Spora bulat, berwarna kuning kecoklatan, tidak bereaksi dengan } \\
\text { melzer, permukaan kasar. }\end{array}$ \\
\hline
\end{tabular}

\section{Kolonisasi Akar}

Kolonisasi akar dapat ilihat berapa banyak persen infeksi suatu akar yang telah dikolonisasi oleh FMA atau tidak dan sekaligus sebagai penentu derajat perkembangan mikoriza pada perakaran. Perlakuan pupuk $\mathrm{P}$ dan FMA tidak berpengaruh nyata terhadap variabel kolonisasi akar. Hasil penelitian menunjukkan (Gambar 1), bahwa perlakuan dengan pemupukan $\mathrm{P}$ dan FMA mycofer $\left(\mathrm{P}_{1} \mathrm{M}_{2}\right)$ memiliki nilai kolonisasi akar tertinggi yaitu $69.7 \%$ yang termasuk kategori tinggi menurut (O'Connor, Smith, \& Smith, 2001) dan kelas 4 menurut (Rajapakse \& Miller, 1992). Terdapatnya infeksi pada perlakuan tanpa pemupukan dan tanpa FMA $\left(\mathrm{P}_{0} \mathrm{M}_{0}\right)$ diduga karena selama di pembibitan, akar-akar pada perlakuan tersebut sudah keluar dari polibag, adanya penyiraman ataupun terbawa angin sehingga spora FMA mampu berpindah.

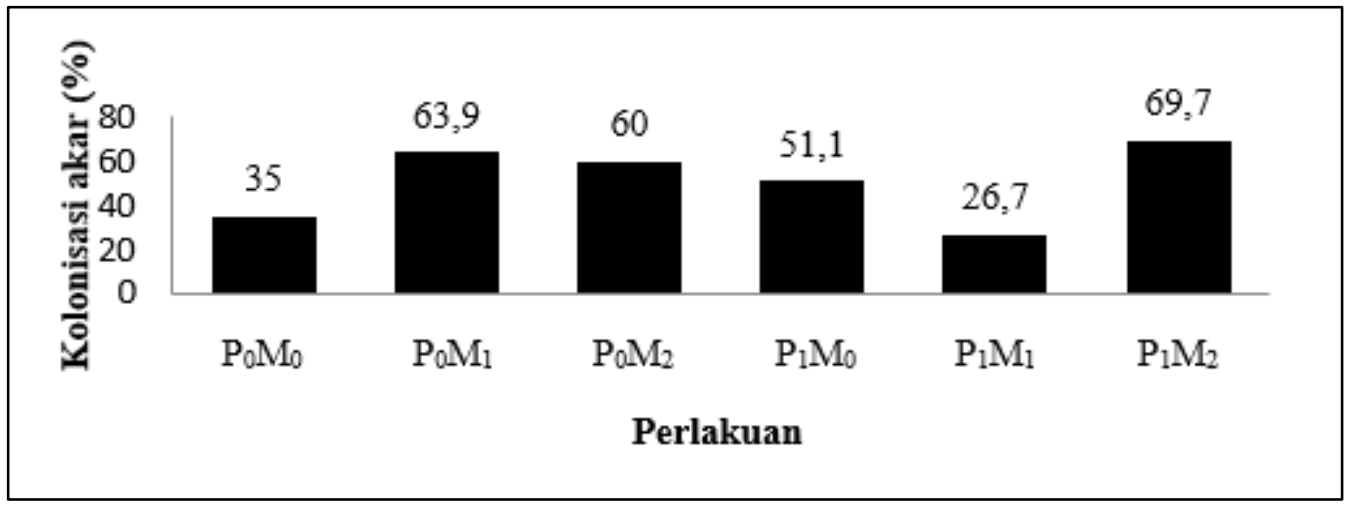

Gambar 1. Diagram kolonisasi akar bibit aren berumur 19 bulan. $\mathrm{P}_{0} \mathrm{M}_{0}=$ tanpa pemupukan $\mathrm{P}$; tanpa FMA, $\mathrm{P}_{0} \mathrm{M}_{1}=$ tanpa pemupukan $\mathrm{P}$; FMA indigenous, $\mathrm{P}_{0} \mathrm{M}_{2}=$ tanpa pemupukan $\mathrm{P}$; FMA mycofer, $\mathrm{P}_{1} \mathrm{M}_{0}=$ pemupukan $\mathrm{P}$; tanpa FMA, $\mathrm{P}_{1} \mathrm{M}_{1}=$ pemupukan $\mathrm{P}$; FMA indigenous, dan $\mathrm{P}_{1} \mathrm{M}_{2}=$ pemupukan $\mathrm{P}$; FMA mycofer.

Asosiasi FMA bersama bibit aren dapat dilihat dari hasil penelitian ini menunjukkan bahwa selain terdeteksi memiliki hifa internal, juga memiliki vesikula setelah bibit aren berumur 19 bulan. Adapun bentuk hifa dan vesikula dapat dilihat pada Gambar 2. 


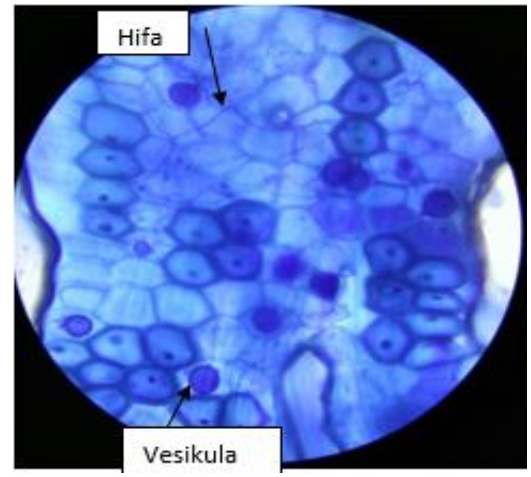

Gambar 2. Hifa dan vesikula yang ditemukan pada akar bibit aren berumur 19 bulan.

\section{Pembahasan}

Pemberian perlakuan pupuk $\mathrm{P}$ dan inokulasi FMA tidak berpengaruh nyata terhadap variabel pengamatan, berarti perlakuan pemupukan maupun inokulasi FMA memberikan hasil yang sama pada pertumbuhan bibit aren. Hal ini serupa dengan hasil penelitian (Palasta \& Rini, 2017) yang menyebutkan bahwa inokulasi FMA tidak dipengaruhi oleh dosis pupuk $\mathrm{P}$ selama di pembibitan pada pertumbuhan tanaman kelapa sawit. Penelitian (Yunus, Syafruddin, \& Syamsuddin, 2016) menyatakan bahwa variabel pengamatan tinggi tanaman, jumlah pelepah daun, diameter batang, serapan unsur hara NPK, dan akar terkolonisasi tidak berpengaruh nyata pada dosis FMA spesifik lokasi.

Pertumbuhan aren yang relatif lambat, sesuai dengan penelitian (Smits, 1996) yang menyebutkan bahwa pelepah daun tanaman aren akan bertambah sebanyak 3-6 helai pelepah tiap tahunnya. Perlakuan pemupukan $\mathrm{P}$ dan inokulasi FMA pada bibit aren setelah berumur 19 tidak berbeda nyata untuk perlakuan tinggi tanaman, jumlah pelepah daun, panjang rachis, dan diameter, hal ini serupa ketika bibit aren masih berumur 24 MSP (Miska, 2015).

Terdapatnya spora pada bibit aren (kontrol) dikarenakan bibit aren yang tidak dirawat dengan baik sehingga akar bibit aren sudah keluar dari polibag yang menyebabkan spora menjadi berpindah pada bibit aren yang semula tidak diberi perlakuan FMA. Hasil penelitian menunjukkan bahwa spora berukuran kecil-kecil dikarenakan sedang bersporulasi, sehingga perlu keteliian dalam mengamati jumlah spora tersebut. Populasi spora FMA dipengaruhi oleh beberapa faktor, misalnya jumlah spora FMA yang tertinggi ditemukan pada tanah dengan nilai $\mathrm{pH}$, P-total dan C-organik yang rendah (Yusriadi, Pata'dungan, \& Hasanah, 2018). Demi memberikan kesempatan spora berkecambah dan membentuk spora baru hendaknya dilakukan trapping di rumah kaca (Suharno, Tanjung, Agustini, \& Sufaati, 2015).

Hasil penelitian (Janting, Muin, \& Burhanuddin, 2018) menyebutkan bahwa guna mempercepat pertumbuhan bibit aren di persemaian ada baiknya menggunakan pupuk organik kotoran ayam sebanyak 350 $\mathrm{g}$ polibag $^{-1}$ dan kapur dolomit $35 \mathrm{~g}^{\text {polibag }}{ }^{-}$ 1 karena mampu memperbaiki sifat fisik, kimia dan biologi tanah. Berdasarkan penelitian (Miska, 2015), pemupukan $\mathrm{P}$ yang diberikan sebanyak $6.3 \mathrm{~g}^{\text {polibag }}{ }^{-1}$, hal ini belum mampu mencukupi untuk kebutuhan pertumbuhan bibit aren. Selain itu, penyerapan hara pupuk $\mathrm{P}$ yang tidak maksimal dikarenakan tercuci oleh air hujan.

Genus spora FMA yang ditemukan pada bibit aren berumur 19 bulan adalah Acaulospora sp, Gigaspora sp, dan Glomus sp. Hasil isolasi danidentifikasi spora FMA yang mendominasi adalah genus Glomus sp. Seperti hasil penelitian (Kurnia, Gusmiaty, \& Larekeng, 2019) sekitar 73.3\% kelimpahan relatif Glomus sp. pada tegakan nyatoh (Palaquium sp.), genus glomus dengan 8 spesies pada tegakan 
ekaliptus (Eucalyptus pellita) (Hermawan, Muin, \& Wulandari, 2015)

Acaulospora sp. merupakan genus mikoriza yang termasuk ke dalam famili Acaulosporacee. Genus ini memiliki beberapa ciri khas berupa ukurannya antara $100-400 \mu \mathrm{m}$, berbentuk globose hingga subglobose, berwarna hialin, kuning, orange kecoklatan, maupun merah kekuningan, memiliki sporiferous saccule, adanya cycatrix sebagai tanda,memiliki bentuk bermacam-macam ornamen tergantung pada spesiesnya, dan memiliki 2-3 dinding spora (Morton \& Benny, 1990) (Nusantara, Bertham, \& Mansur, 2012) (INVAM, 2019).

Gigaspora sp. adalah genus yang tergolong ke dalam famili Gigasporaceae yang memiliki ciri berupa ukuran spora $125-600 \mu \mathrm{m}$, berwarna krem hingga kuning, berbentuk globose hingga subglobose, tidak memiliki ornamen, hanya memiliki 1 dinding spora yaitu pada lapisan dinding luar saja, dan memiliki sel auksilari (auxilary cell) yang merupakan perwujudan dari vesikula eksternal (Morton \& Benny, 1990) (Nusantara, Bertham, \& Mansur, 2012) (INVAM, 2019).

Glomus sp. merupakan genus mikoriza yang termasuk dalam famili Glomeraceae yang bercirikan berukuran 20 - $400 \mu \mathrm{m}$, berbentuk globose, subglobose, elips, ataupun tidak beraturan, memiliki warna hialin sampai kuning, merah kecoklatan, coklat dan hitam, dinding spora lebih dari 1 lapis (berlapislapis), memiliki sporogenus cell, spora terbentuk secara tunggal atau pun berpasangan, terdapat dudukan hifa, dan tidak memiliki ornamen (subtending hypae) lurus (Morton \& Benny, 1990) (Nusantara, Bertham, \& Mansur, 2012) (INVAM, 2019).

Berdasarkan penelitian (Miska, 2015), bibit aren berumur 24 MSP hanya ditemukan terinfeksi berupa hifa, namun penelitian ini bertambah dengan adanya vesikula. Hal ini sama dengan hasil penelitian (Siregar, 2017) yang menyebutkan bahwa pada akar tanaman kelapa sawit terdapat hifa dan vesikula.
Terbentuknya hifa berasal dari perkecambahan spora, yang berperan dalam penyerapan air dan unsur hara dari luar akar menuju ke dalam akar. Vesikula berbentuk lonjong atau pun tidak beraturan yang berfungsi sebagai organ penyimpanan cadangan makanan seperti lipid (Peterson, Massicotte, \& Melville, 2004). Spora mengalami perkecambahan dalam menghasilkan hifa untuk menginfeksi akar tanaman inangnya yang berguna untuk memperbanyak diri. Peran utama mikoriza secara agronomis yaitu kemampuannya dalam meningkatan serapan hara tanaman. Permukaan akar lebih cepat dalam penyerapan $\mathrm{P}$ dibandingkan dengan pergerakan phospat ke permukaan akar (Simanungkalit, 2006).

\section{KESIMPULAN}

Evaluasi pertumbuhan bibit aren setelah berumur 19 bulan menunjukkan bahwa perlakuan pemupukan $\mathrm{P}$ dan inokulasi FMA tidak berbeda nyata pada seluruh peubah yang diamati yaitu tinggi tanaman, jumlah pelepah daun, panjang rachis, diameter tanaman, kehijauan daun, jumlah spora dan kolonisasi akar. Bibit aren yang semulanya tidak diberi perlakuan (kontrol), setelah berumur 19 bulan menjadi terinfeksi dan ditemukan adanya spora.

\section{DAFTAR PUSTAKA}

Ariyanti, M., Soleh, M. A., \& Maxiselly, Y. (2017). Respon Pertumbuhan Tanaman Aren (Arenga pinnata merr.) dengan Pemberian Pupuk Organik dan Pupuk Anorganik Berbeda Dosis. J. Kultivasi, 16(1), 271-278.

Bachtiar, Ghulamahdi, M., Melati, M., Guntoro, D., \& Sutandi, A. (2016). Kecukupan Hara Fosfor pada Pertumbuhan dan Produksi Kedelai dengan Budidaya Jenuh Air di Tanah Mineral dan Bergambut. $J$. 
Ilmu Tanah dan Lingkungan, 18(1), 21-27.

Brundrett, M., Bougher, N., Dell, B., Grove, T., \& Malajczuk, N. (1996). Working with Mychorrizas in Forestry and Agricultural. Canberra (AU): Australian Centre for International Agricultural Research.

Effendi, D. S. (2010). Prospek Pengembangan Tanaman Aren (Arenga pinnata Merr) Mendukung Kebutuhan Bioetanol di Indonesia. J. Perspektif, 9(1), 36-46.

Hadianur, Syafruddin, \& Kesumawati, E. (2016). Pengaruh jenis fungi mikoriza arbuscular terhadap pertumbuhan dan hasil tanaman tomat. J. Agrista, 20(3), 126-134.

Hermawan, H., Muin, A., \& Wulandari, R. S. (2015). Kelimpahan Fungi Mikoriza Arbuskula (FMA) pada Tegakan Ekaliptus (Eucalyptus pellita) Berdasarkan Tingkat Kedalaman di Lahan Gambut. $J$. Hutan Lestari, 3(1), 124-132.

INVAM. (2019). Dipetik Juli 26, 2020, dari International Culture Collection of (Vesicular) Arbuscular Mycorrhizal Fungi:

https://invam.wvu.edu/methods/my corrhizae

Janting, Muin, A., \& Burhanuddin. (2018). Pertumbuhan bibit aren (Arenga pinnata Merr) pada media tanah ultisol di persemaian. $J$. Tengkawang, 8(1), 1-5.

KEMENTAN. (2016). Basis Data Statistik Pertanian. Dipetik Juli 16, 2020, dari Kementerian Pertanian Republik Indonesia: https://aplikasi2.pertanian.go.id/bds $\mathrm{p} / \mathrm{id} /$ komoditas

Kurnia, Gusmiaty, \& Larekeng, S. H. (2019). Identifikasi dan Karakterisasi Mikoriza pada Tegakan Nyatoh (Palaquium sp.). J. Perennial, 15(1), 51-57.

Lempang, M. (2012). Pohon Aren dan Manfaat Produksinya. Info Teknis Eboni, 9(1), 37-44.

Malik, M., Hidayat, K. F., Yusnaini, S., \& Rini, M. V. (2017). Pengaruh Aplikasi Fungi Mikoriza Arbuskula dan Pupuk Kandang dengan Berbagai Dosis terhadap Pertumbuhan dan Produksi Kedelai (Glycine max [L.] Merrill) pada Ultisol. J. Agrotek Tropika, 5(2), 63-67.

Manahan, Putri, L. A., \& Husni, Y. (2014). Respons Pertumbuhan Bibit Aren (Arenga pinnata Merr) terhadap Pemberian Pupuk Organik Cair. $J$. Online Agroteknologi, 2(2), 460471.

Mashud, N., Maliangkay, R. B., \& Nur, M. (2013). Pengaruh Pemupukan terhadap Pertumbuhan Vegetatif Tanaman Aren Belum Menghasilkan. B. Palma, 14(1), 1319.

Miska, M. E. (2015). Respon Pertumbuhan Bibit Aren (Arenga pinnata (Wurmb) Merr.) terhadap Inokulasi Fungi Mikoriza Arbuskula Indigeneous [tesis]. Institut Pertanian Bogor. Bogor (ID): Institut Pertanian Bogor.

Morton, J. B., \& Benny, G. L. (1990). Revised Classification of Arbuscular Mychorrizal Fungi 
(Zygomycetes). Mycotaxon, 37, 471-491.

Novita, D., Kesuma, B. W., \& Susilo, E. (2017). Aplikasi Pupuk Organik Cair Berbahan Limbah Kulit Buah Aren (Arenga pinnata Merr.) untuk Meningkatkan Potensi Pertumbuhan dan Hasil Kedelai di Tanah Ultisol. J. Agroqua, 15(1).

Nuryani, E., Haryono, G., \& Historiawati. (2019). Pengaruh Dosis dan saat Pemberian Pupuk P terhadap Hasil Tanaman Buncis (Phaseolus vulgaris, L) Tipe Tegak. J. Ilmu Pertanian Tropika dan Subtropika, 4(1), 14-17.

Nusantara, A. D., Bertham, Y. H., \& Mansur, I. (2012). Bekerja dengan Fungi Mikoriza Arbuskula. Bogor (ID): SEAMEO BIOTROP.

O'Connor, P. J., Smith, S. E., \& Smith, F. A. (2001). Arbuscular Mycorrhizal Associations in the Southern Simpson Desert. Australian Journal of Botany, 49, 493-499.

Palasta, R., \& Rini, M. V. (2017). Pertumbuhan Bibit Kelapa Sawit dengan Aplikasi Fungi Mikoriza Arbuskular dan Beberapa Dosis Pupuk Fosfat. J. Agro Industri Perkebunan, 5(2), 97-106.

Peterson, R. L., Massicotte, H. B., \& Melville, L. H. (2004). Mychorrhizaz : Anatomy and Cell Biology. Ottawa (CA): NRC Research Press.

Rajapakse, S., \& Miller, J. C. (1992). Methods for Studying VesicularArbuscular Mycorrhizal Root Colonization and Related Root
Physical Properties. Sandiego (US): Academic Pr.

Sebayang, L. (2016). Keragaan Eksisting Tanaman Aren (Arenga pinnata Merr) di Sumatera Utara. $J$. Pertanian Tropik, 3(2), 133-138.

Simanungkalit, R. D. (2006). Cendawan Mikoriza Arbuskuler. Dalam R. D. Simanungkalit, D. A. Suriadikarta, R. Saraswati, D. Setyorini, \& W. Hartatik, Pupuk Organik dan Pupuk Hayati (hal. 159-190). Bogor (ID): Balai Besar Penelitian dan Pengembangan.

Siregar, N. (2017). Inveksi Fungi Mikoriza Arbuskula pada Akar Tanaman Kelapa Sawit (Afdeling II dan III di PTPN III Kebun Batang Toru). J. Education and development STKIP Tapanuli Selatan, 6(4), 31-33.

Smits, W. T. (1996). Arenga Pinnata, (Wurmb) Merrill. Bogor (ID): Prosea Foundation.

Suharno, Tanjung, R. H., Agustini, V., \& Sufaati, S. (2015). Keragaman Fungi Mikoriza Arbuskula pada Tumbuhan Pokem (Setaria italica (L). Beauv.] dengan Metode Trapping. J Biologi Papua, 7(2), 68-77.

Utari, A. (2018). Pemanfaatan Limbah Kulit Buah Aren sebagai Pupuk Kompos terhadap Evaluasi Nutrisi Silase Rumput Gajah pada Ternak Ruminansia. J. Eksakta, 3(1), 9-24.

Yunus, M., Syafruddin, \& Syamsuddin. (2016). Pemanfaatan Fungi Mikoriza Arbuskular Spesifik Lokasi dan Pupuk Kompos Tandan Kosong Kelapa Sawit pada Tanah Ultisol terhadap Pertumbuhan 
Tanaman Kelapa Sawit (Elaeis guineensis Jacq). J. Agrista, 20(3), 150-160.

Yusriadi, Pata'dungan, Y. S., \& Hasanah, U. (2018). Kepadatan dan Keragaman Spora Fungi Mikoriza Arbuskula pada Daerah Perakaran Beberapa Tanaman Pangan di Lahan Pertanian Desa Sidera. $J$ Agroland, 25(1), 64-73.

\section{UCAPAN TERIMA KASIH}

Ucapan terima kasih penulis haturkan setinggi-tingginya kepada SEAMEO BIOTROP yang telah memfasilitasi penelitian ini dari proses pengamatan di lokasi pembibitan maupun di laboratorium Silvikultur sampai selesai. 